\title{
H. SHIMADA, M.D. : THE HISTOLOGICAL STUDIES ON THE SEUSORIUM OF THE EAR-LABYRINTH DURING ALCOHOL-NYSTAGMUS (Report II)
}

\section{酒精眼震發現時に於ける迷路感覺終末部の. 組 織學 的 研 究 (II)}

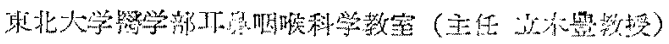
鼠思弘 共

\section{IV) 媳括並び考按}

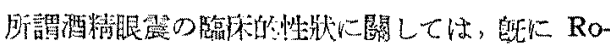

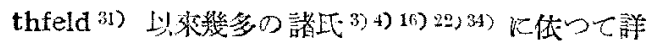

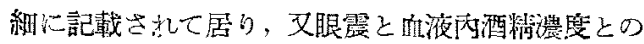

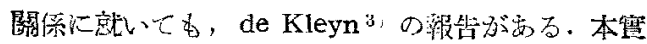

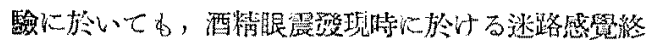

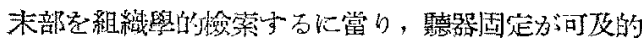

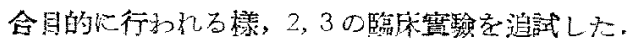

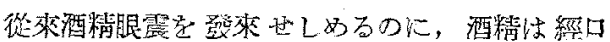

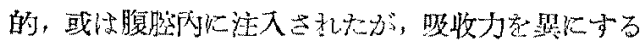

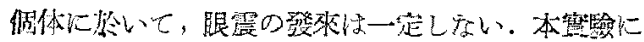

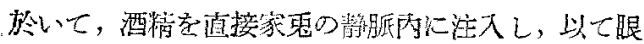

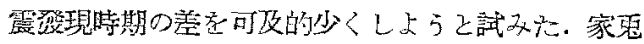

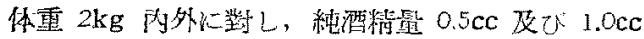

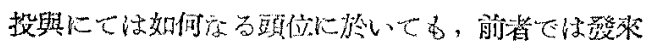

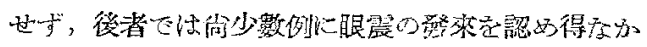

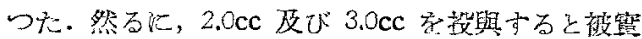

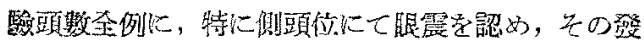

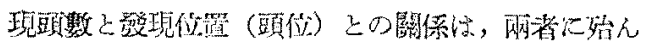

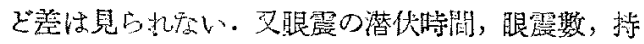

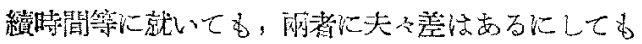
著しい差は認为藋い，從つて聽器固定漈しては，

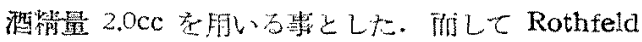

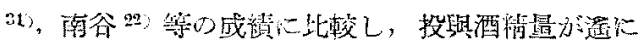

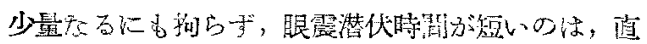

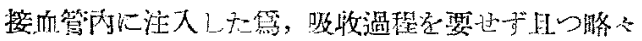

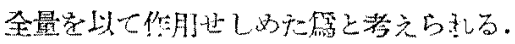

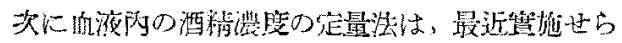

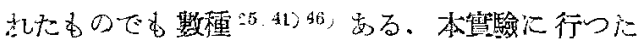
Newman 洗を胢いて，本邦では缜崎，森下”，枝 5. 等の報台がある。 de Kleyn ${ }^{3)}$ は, Widmark 法

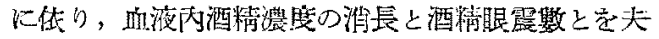

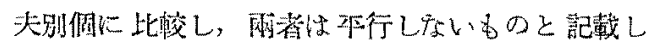
‡.

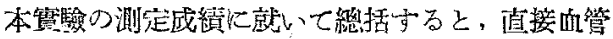

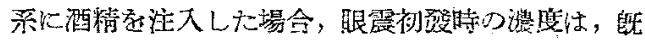

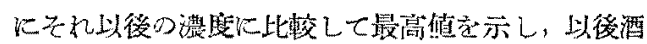

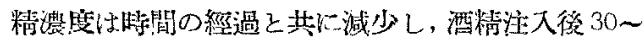
60 分迄は稍々急涑に，その後怯稍々緩徐減少の途

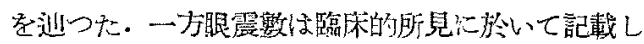

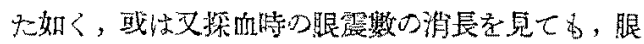

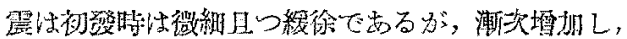
概水酒精注入後 5〜15 分化して最高調に澾し，以後

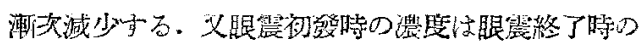

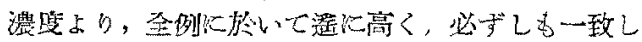

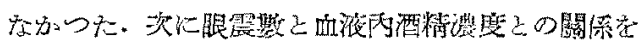

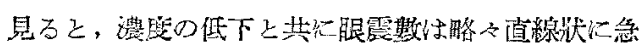

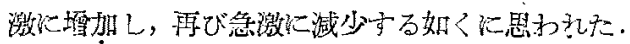

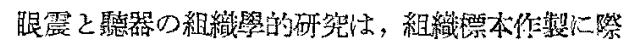

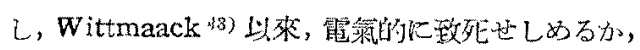

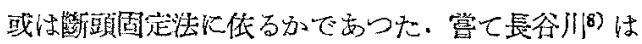

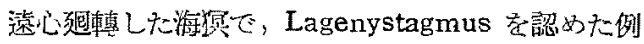

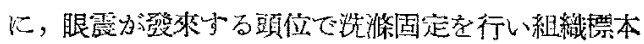

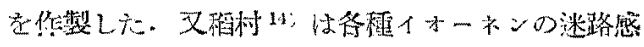

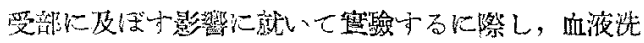

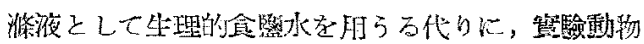

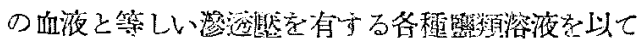

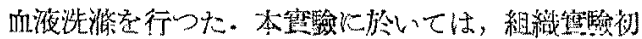

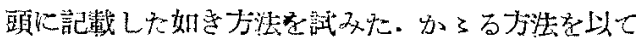

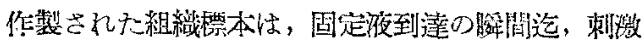
源である必要量の酒精性生理的食隭水と其江灌流

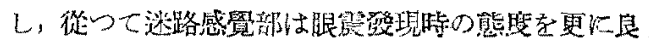




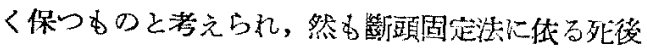

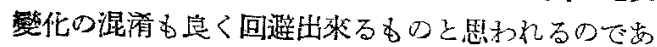
子.

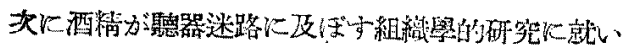

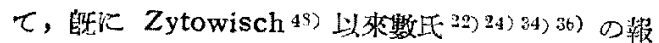

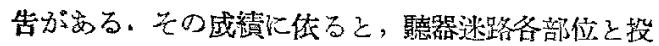
與された酒精量との戀化の渡合は必ずしす本行する

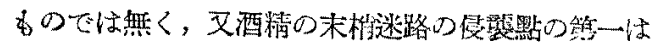

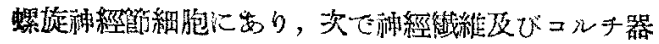

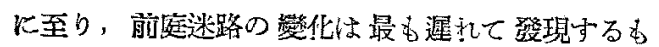

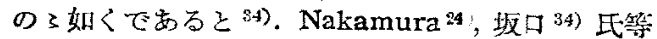

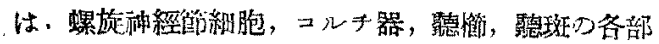
位の變化に就いて記載し，Zytowisch $4 s$ は，闪外

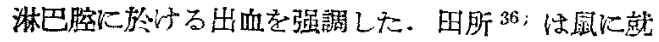

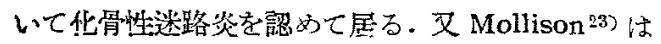

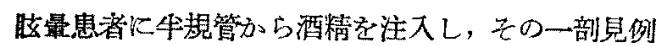
K就いて，Hollpike は Scarpa E种經战細胞の退

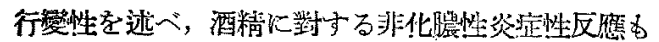

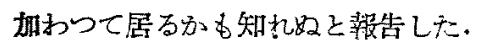

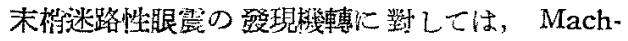
Breuer の淋巴流動新と，Wittmaack $の$ Tonus

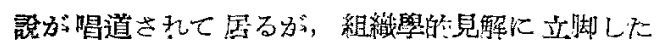

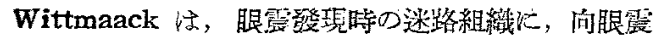
側には kompressiv の戀化它，反對侧には depr-

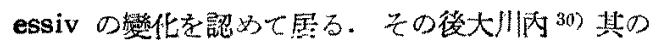

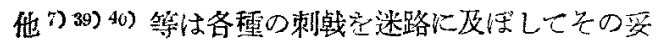
䉥㧼学論じて屋る。

叉 Lagenystagmus に慗いては，Bárány 1)の

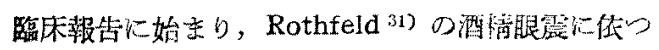

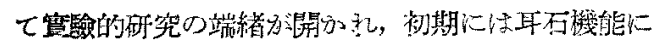

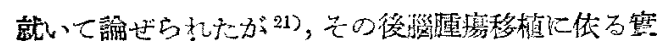

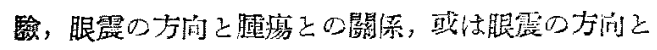

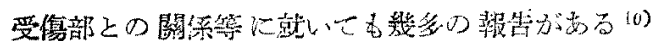

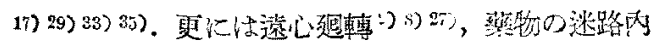

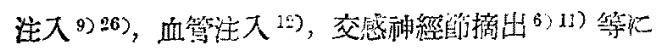

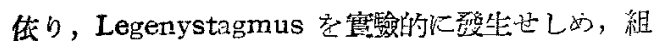

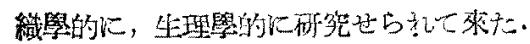

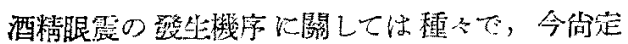

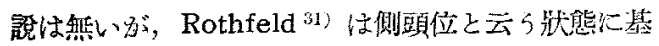

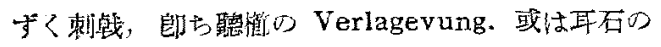

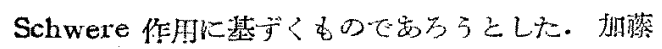
$6-33$

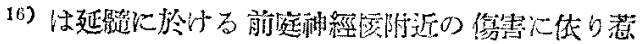

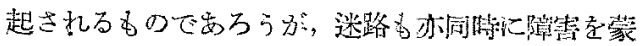

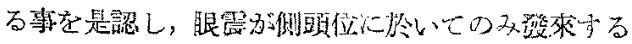

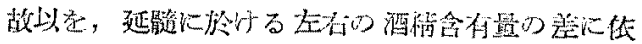

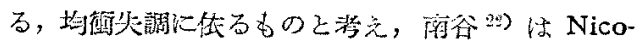

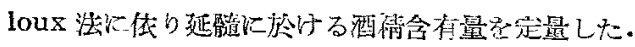

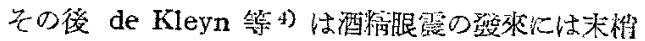

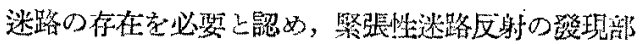

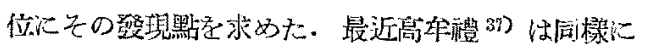

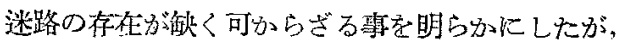

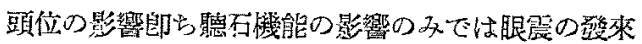

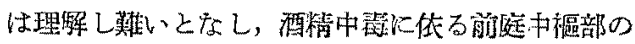

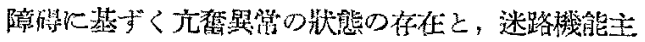

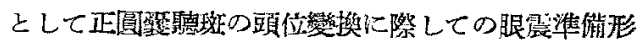

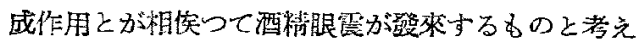
t.

譒つて，以下本售驗に依つて得大組織所見に裁い て總括して見る.

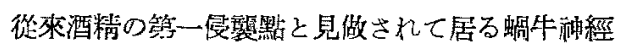

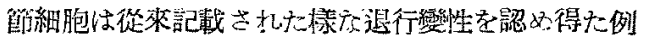

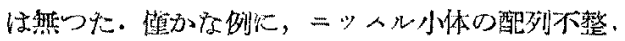

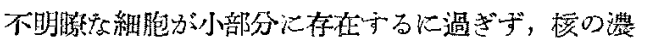

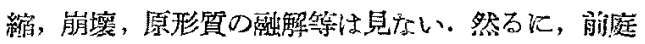
迷路に於汁る感覺, 败性細胞, 或はコルチ器各細

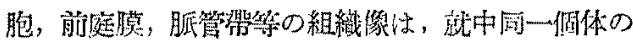
上位耳，下位耳を比較する時，必ずしる同じ元鹪状 態に在るとは云い蜼い幾多の例を得大，此の事賈

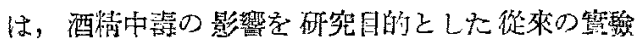

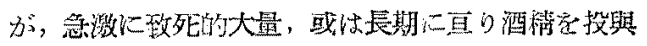
し，以て慢性酒精中毒に陷らしめたのに罂し，來䇺

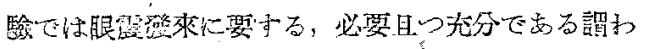

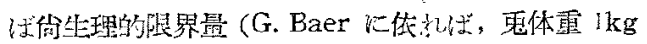

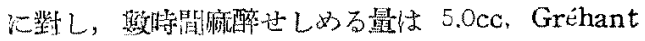

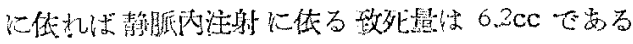

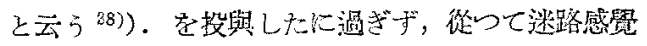

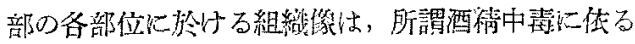

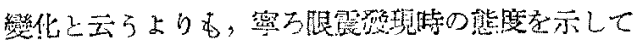

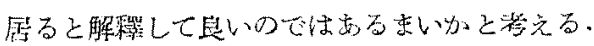

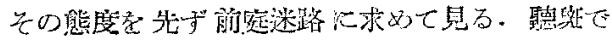

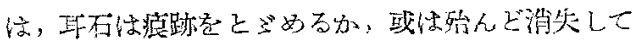

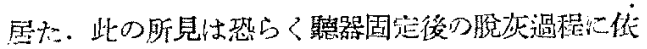




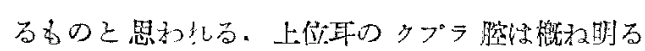
く，織維の走间名䀩ふ平行して走る例が多い，中下

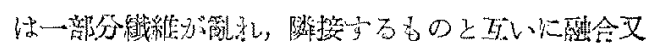

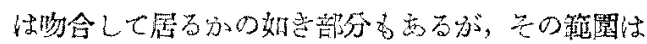

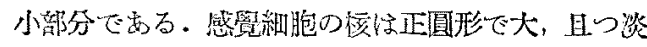

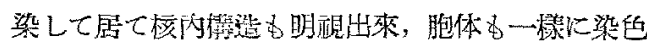

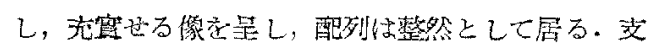

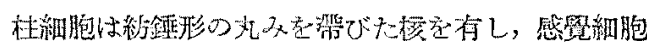

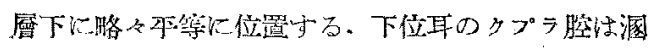

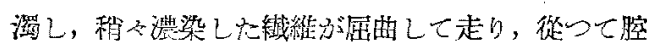

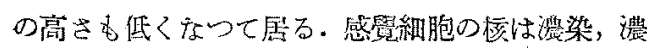

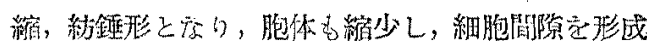
し，不覞則にならび，支杜細胞は乞の粗なる間烸に

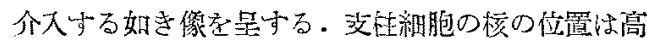

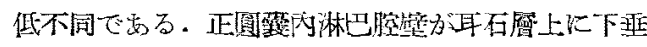

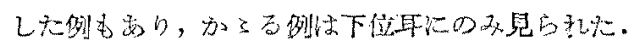

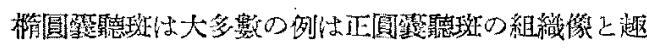

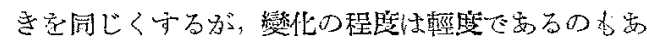

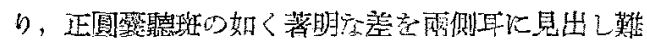
准安岕る。

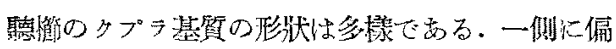

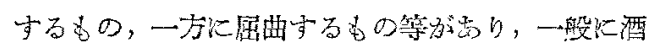

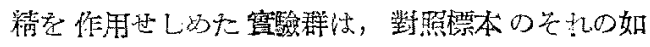

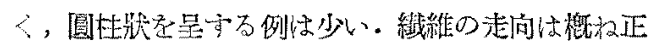

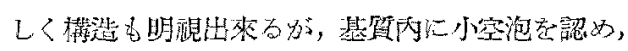

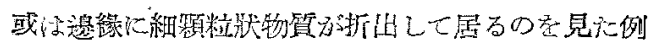

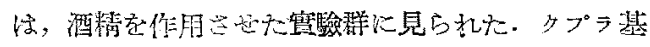

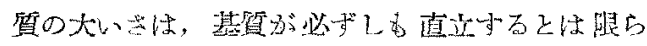

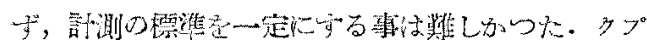

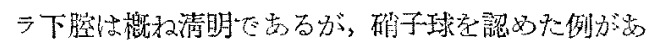

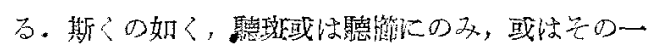

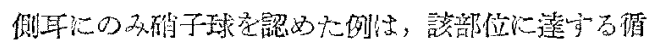

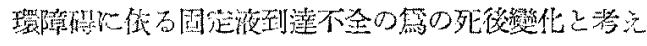

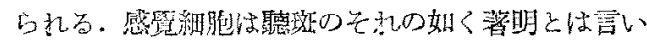

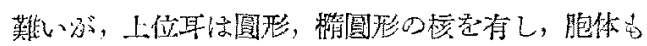

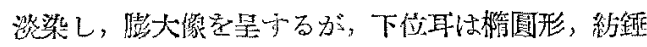

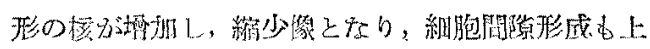

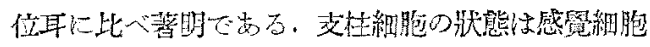

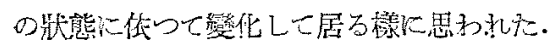

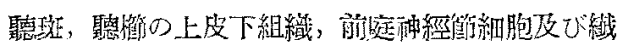
維に著督数見出し蜼い。
次竘牛迷路の組織像汇就いて總括寸る．內外淋 巴腔は大多數满澄で炎症情細胞，出血等は見られな

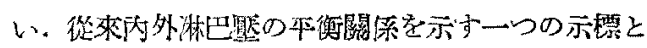

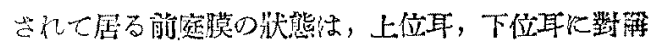
的な位置を示才例を倯々多數得た。郎ち上位耳で

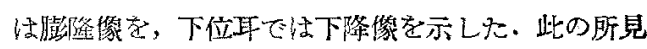

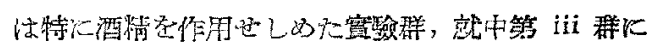

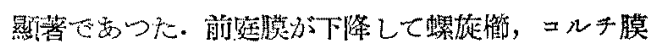
上飞垂下して居るが和き像は下位耳にの見られ，

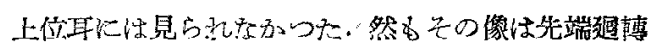
に多く見られた。

脈管斝法內淋巴液分泌によると見做されて居る

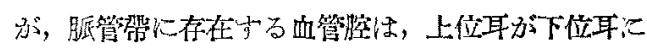

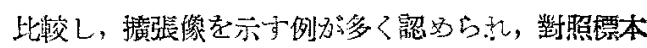
と比較して，下位耳では收綰像を䛑めた例为上位耳

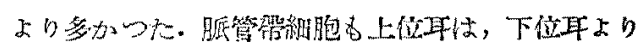
核反び胞低が路大して堅る場合が多い。

コルチ器各細胞住就いて見ると，内外毛細胞の萎

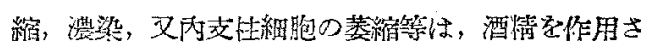
せた標本群炕認められた，ダイテルス、のンゼン， クラウデウス各細胞は，各泪体，各超轉儿依つてそ

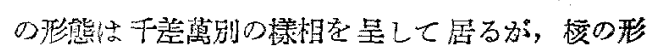

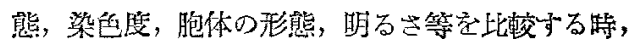

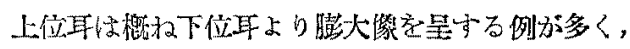

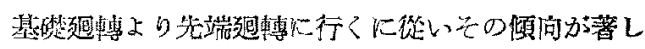

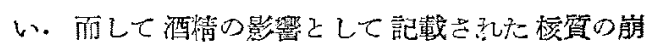
壇，空胞の形成等は見られなかつた。細胞境界の不

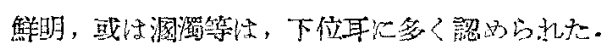

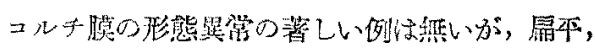

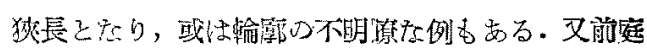

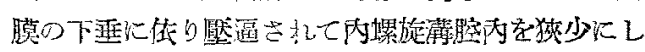

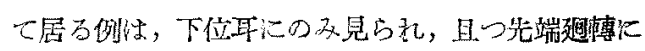
砂。

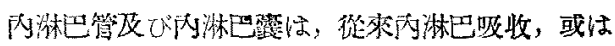

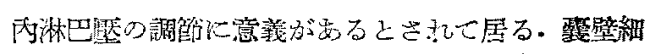

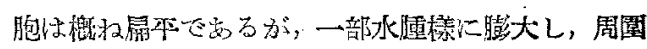

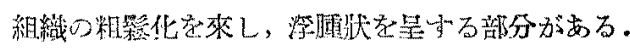

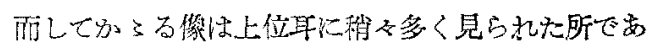

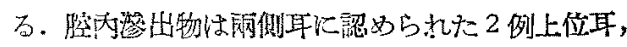
下位耳各々1例で气の做は清澄である。

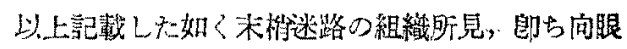


震㑬（下位耳）と反對側（上位耳）の組絨像が，蝸

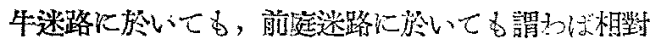

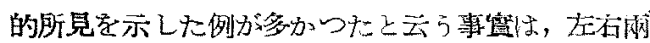

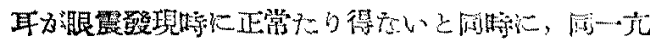

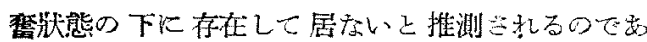

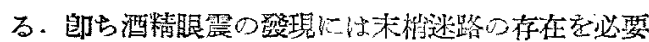

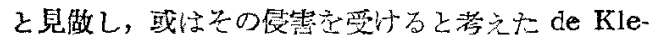

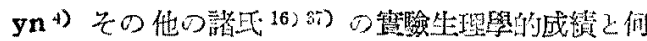
等かの關係名存在与るむのと考々らさる。

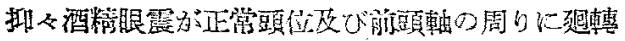

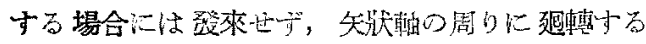

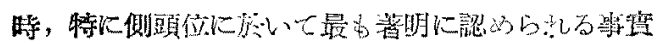

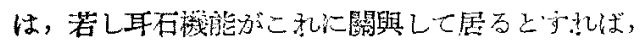

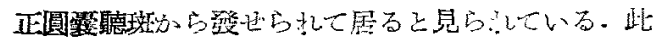

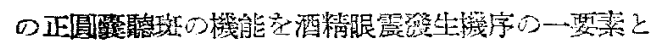

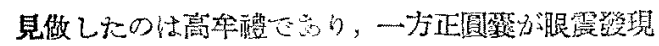
飞無關係々推测したのは de Kleyn 一派でする。

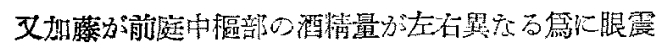

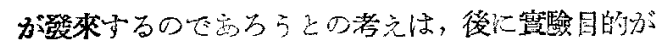

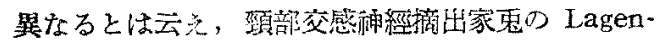

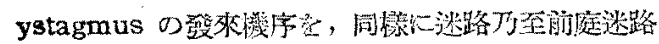
領域に於ける左右血量の差に基ずく々考充た長谷川 6)11等の證と其に興味の方るところである。

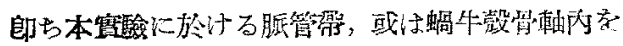

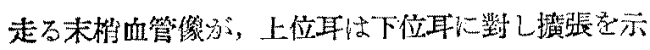

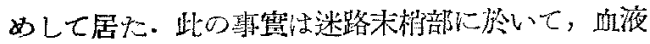
量が夫々巽つて居る事字推測させるものであり，從

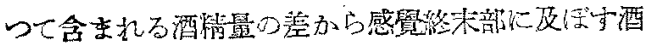

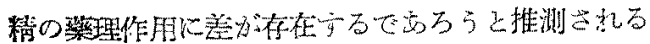

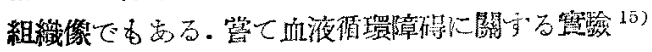

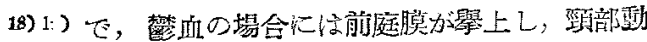

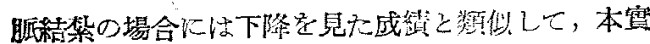

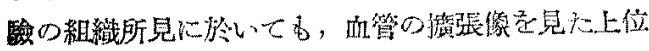

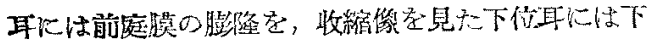

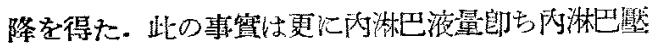
の美が，上位耳下位耳の間に存在して居る囊を思考 せしめるあのでする。

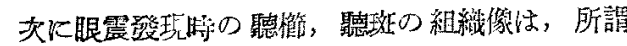

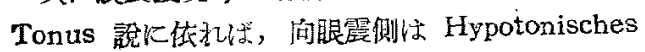
Zellbild (Kompressives Bild), 反對側は Hyper-

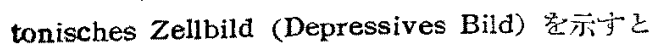

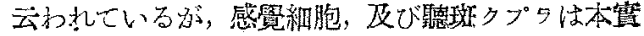

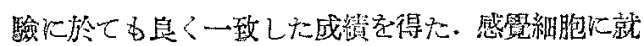

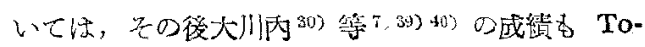

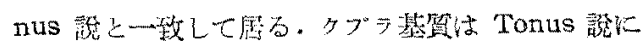

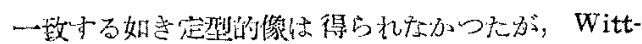

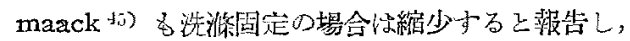

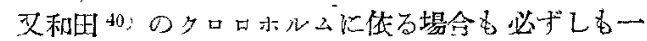

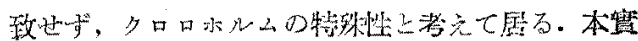

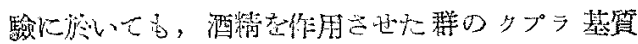

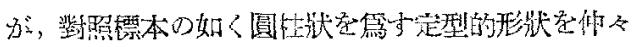

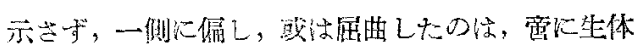

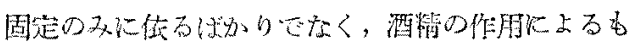

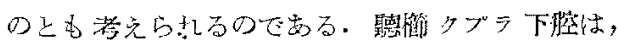

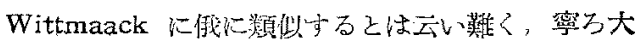

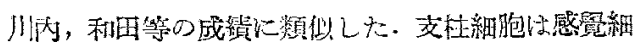

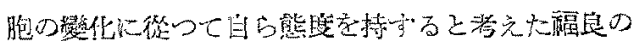

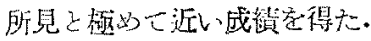

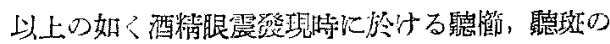

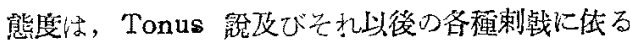

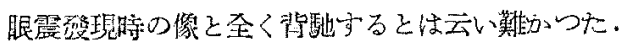

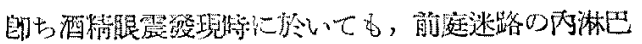

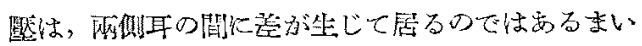
か上考光られるので要る.然も蝸牛迷路の前庭荧， コルチ器各細胞の紎態が，前庭迷路に於ける Kompressives, Depressives Zellbild と略々一致して, 上位耳心澎隆及び膨大像を，下位耳儿下隆区び縮少

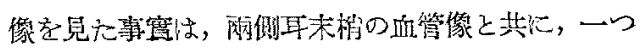

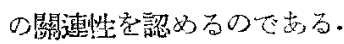

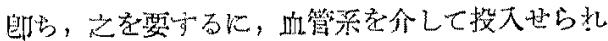

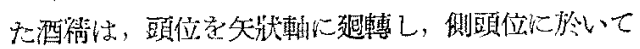

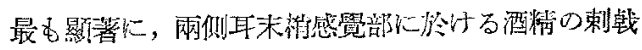

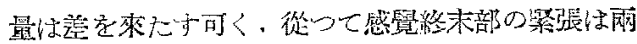

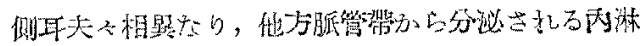

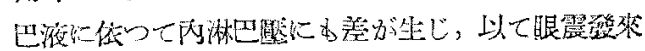

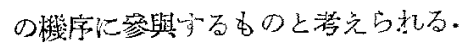

\section{結論}

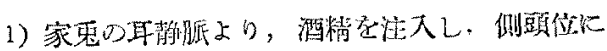

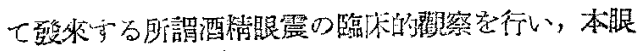

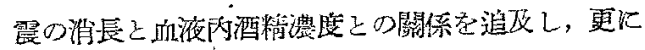

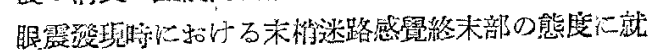




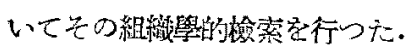

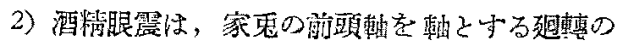

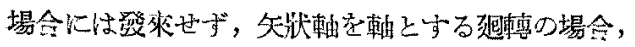

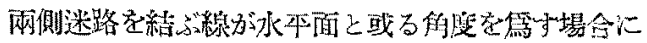

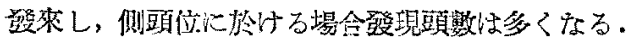

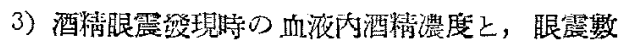

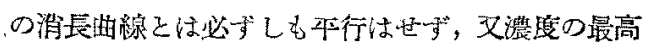

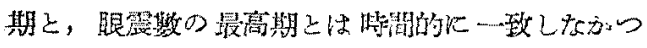
た.

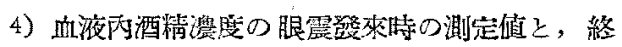

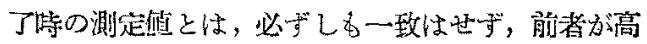
力口小.

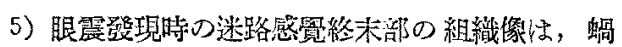

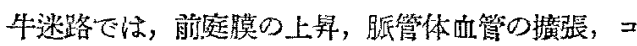

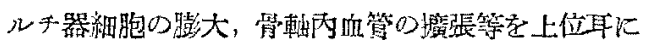

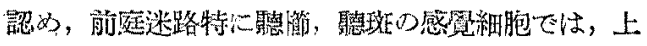

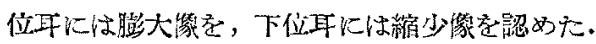

6) 以上の組織捞から，而智系を介して投與され た酒棈は，末梢迷路に於いては各感學終末部に作用

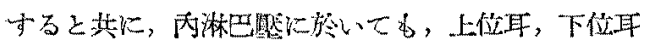

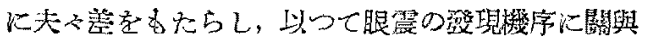
ホるすので㖶ららと推諭された。

\section{主要献文}

1) Bárány: Mschr. Ohrenh. k. 45. 19:1. 959.

2) Chilow: Zsch f. H. usw h. k. 17, 1927. 483.

3) de Kléyn: Ino-Kubo Festschrift 1934. 187.

4) de Kléyn $u$. Versteegh: Acta otolaryng 14.

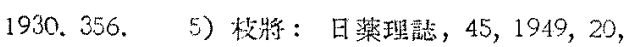

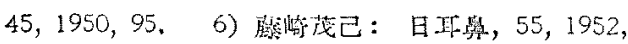
91. 7) 福良政雄: 大日耳菱，45，1939，1250， 45, 1939, 1224. 8) Hasegawa: Pflüger Arch. 229,1931.205. 9) Hasegawa: Msch, ohrenh.

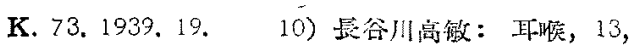

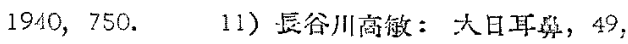

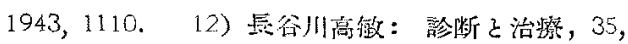
1947, 133. 13) Heffer: Handbuch d. Experiment, Pharmakolog, 14) 稳柯正三：日正

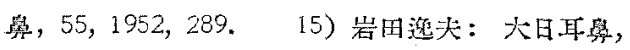

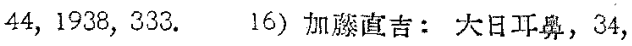

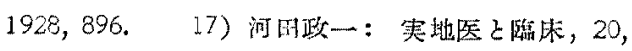

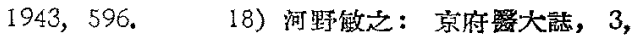

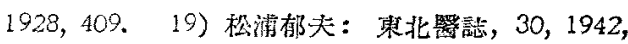

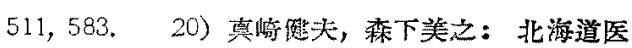
祘, 19,1941, 1823. 21) Meyer zum Gottesberge: Z. b. l. Hals-usw H. K. 33. 1939.1. 22) 南谷広第：朝焦医誌，20,1930. 23) Mollison: Acta oto-laryng. 27. 1939, $222 . \quad 24) \mathrm{Naka-}$ mura: Beitr. Anat, usw. Ohr. usw 8. 1916. 41. 25) Newman: J. of Pharmacol. 56. 1936. 278. 26) Nylén: Acta oto-laryng. 13. 1929. 302. 27) Nylén: Acta oto-laryng. 9. 1926. 179. 28) Nylên: Acta ơto-laryng, 11, 1927. 147. 29) Nylén: Acta oto-laryng suppl. 33.

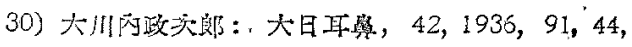
1938, 131. 31) Rothfeld: Arb. a. d. neurol. Inst. d. Wien Univ. 29. 1913.89. 32) $\boldsymbol{R} u$ nge: Deutsch. med. Wochenschr. 50. 1924. 33) Ruttin: Z. Hals-usw H. K. 27. 1930. 606.

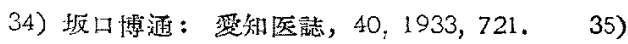
Seiferth: Z. Hals-usw. H. K. 37, 1935. 367.

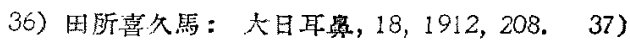

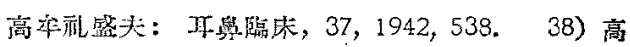

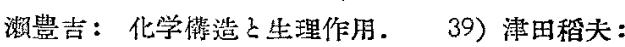

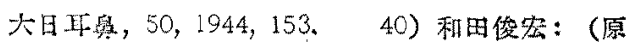
韯発表予定). 41) Widmark: Biochem. Zsch. 131. 1922. 473. 42) Wittmaack: Acta oto-laryng. 22.1935. 557.4 43) Wittmaack: Arch. Ohrenh. K. 114. 1926. 278. 44) Wittmaack: Arch Ohrenh. K. 120. 1929. 256. 45) Wittmaack: Arch. Ohrenh. K. 135. 1933, 41. 46) Yamakami: Tohoku. J. Experm. med. 4.

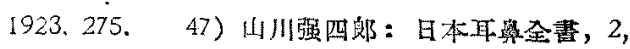
1935, 422. 48) Zytowisch: Arch. Ohrenh. K. $88,1912.88$.

\section{附圖境明}

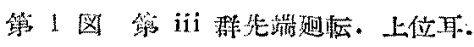

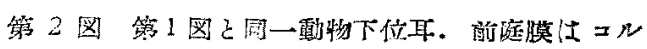
手膜趾端被う，コルチ栄各細胞は上位 円より縮少し，胍管帶の血管は上位耳よ り收縮寸。 
島田論文附圖
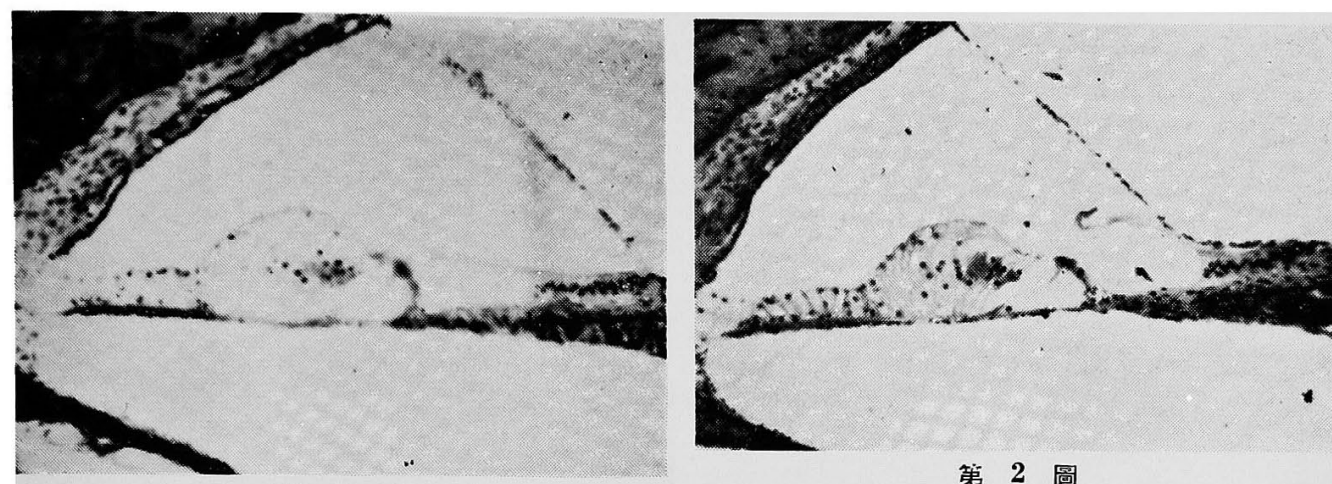

第 1 圖

第 2 圖

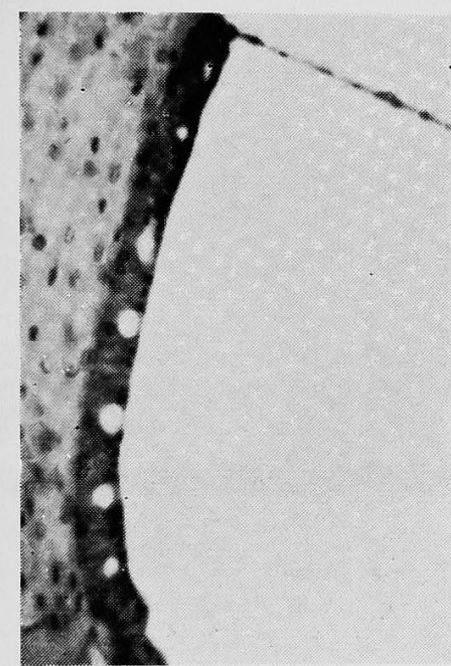

第 3 圖
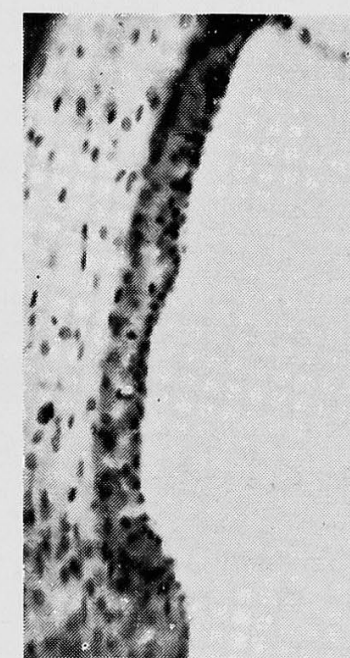

第 4 圖

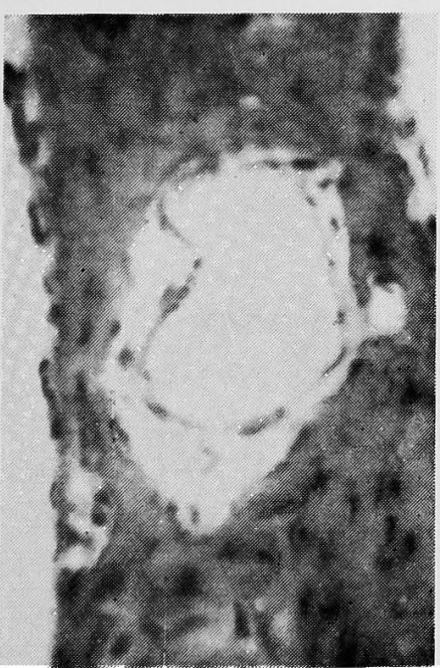

第 5 圖

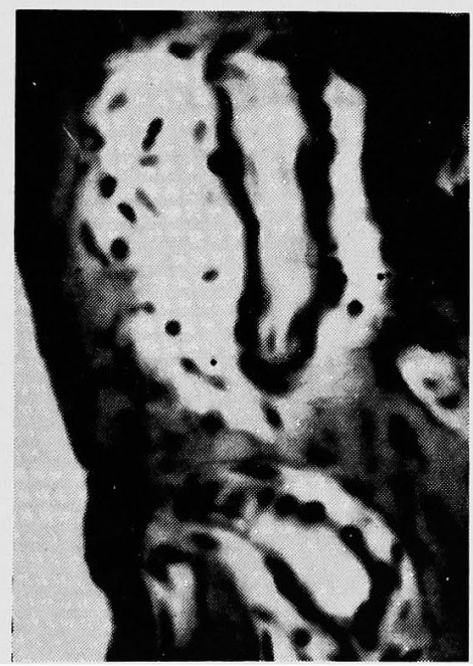

第 6 圖 


$$
\text { 島田猃文附圖 }
$$

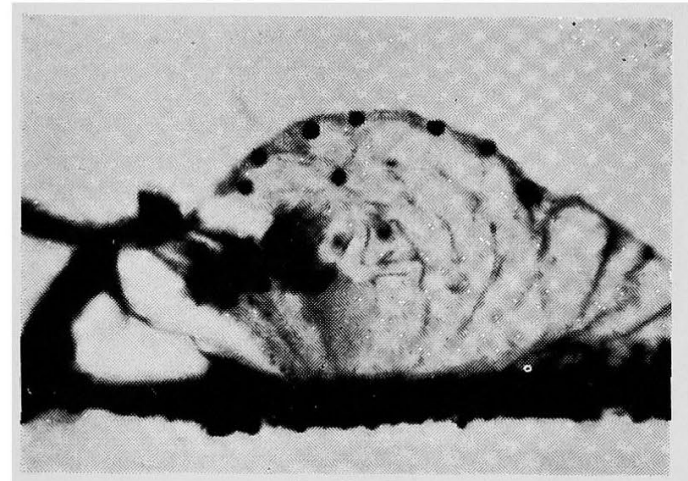

第 7 圖

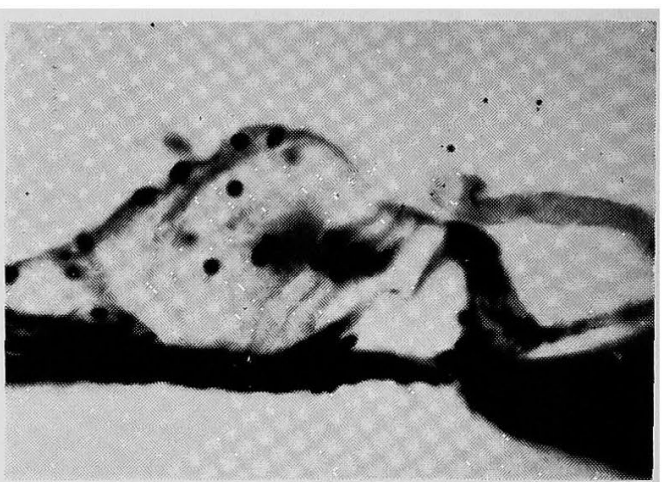

第 8 圖

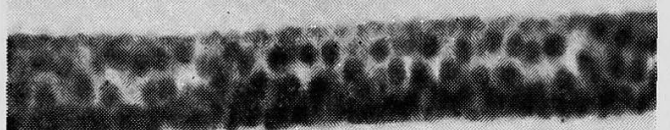

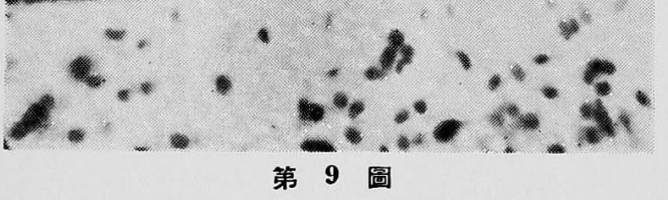

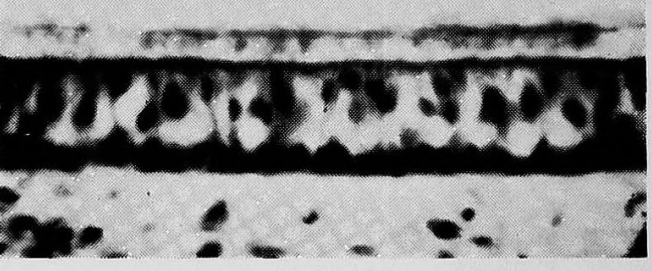

第 10 圆

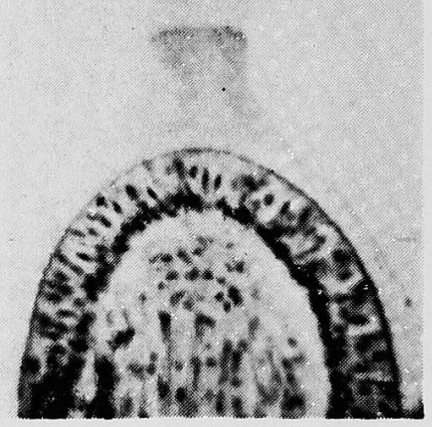

第 11 圖

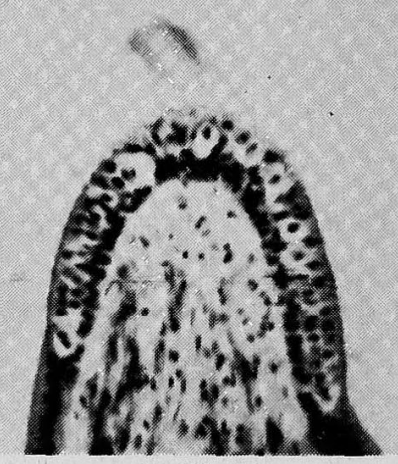

第 12 圖 


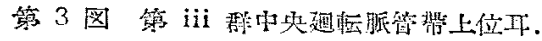

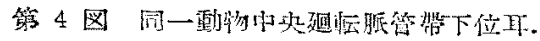

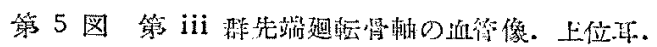

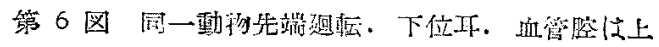
位評に比し收縮寸。

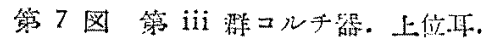

第 8 図网一動物。下位耳。

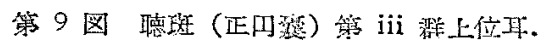

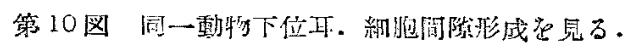

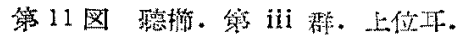

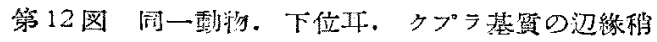

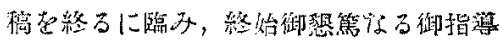

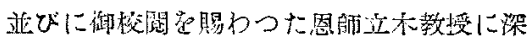

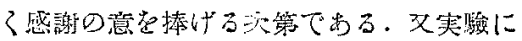

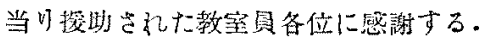

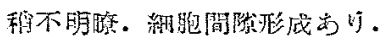

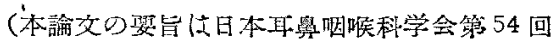
総会に発䓂した.)

（原慗到着＝绍相28.11.29 日）

Y. YAMAKAWA, M.D.: ABOUT THE STATICAL FUNCTION OF THE LABYRINTH AFTER THE FENESTRATION OPERATION

\section{迷路開空術後の平衡機能}

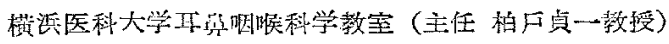

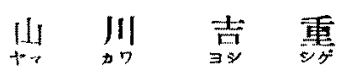

\section{緒㝘}

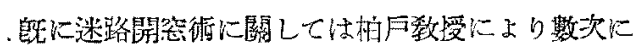

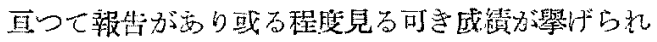
るといら事力澄明せら机た。然し乍ら本手沺は水平

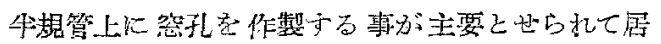

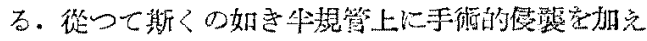

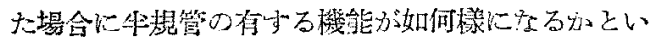
ら事は一の董大な開題こむらねばならない。

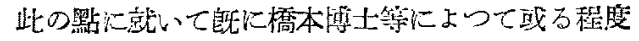

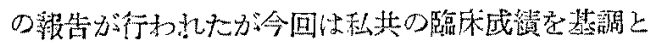
して報皆を致し度い。

\section{觀察方法}

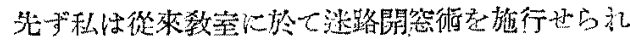

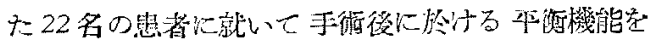

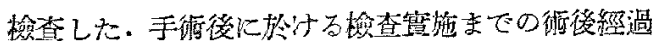
期間は症例汇よつて必す゚しも一定ではない，最短は 術後 16 日，最長惊街後 2 年 5 ケ月に改んでいる。

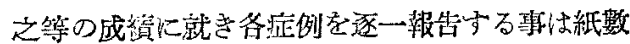
$6-37$
の關係上不可能である故, 先ず著明な症例 2,3 亿就 き其の榴要袁郝告したい。

\section{私の症例 2,3 につて}

管 1 例：男子， 25 才，左耳手街。

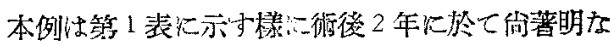

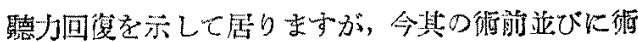

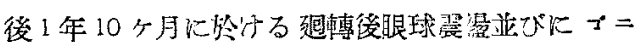

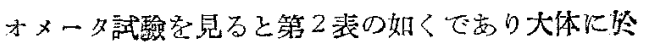

\section{第 1 表}

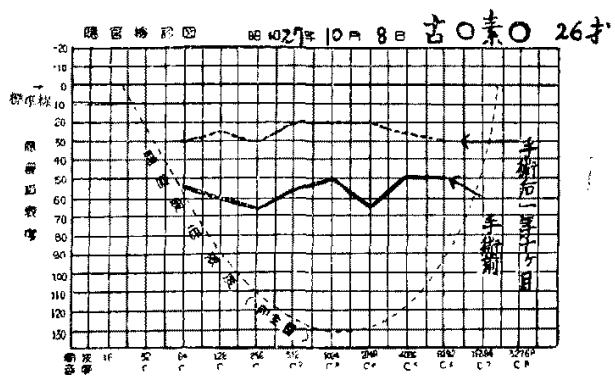

